\title{
Prospects for the development of historical seismology and the study of ancient monuments in Armenia
}

\author{
Laurenti Barséghian \\ International Centre for the Seismic Protection of Historic and Cultural Monuments, Erevan, Armenia
}

\begin{abstract}
After the disastrous earthquake of Spitak in 1988, a new phase of reflection and study on the effects of seismic events opened in Armenia. The tradition of historical studies aimed at reconstructing and expanding the historical series of earthquakes in Armenia can be traced back to the last century, but it is only in the last three decades that it has yielded important results. Over the last few years interest in the matter has been rekindled: new programme of in-depth ave further improved the catalogues of historic earthquakes and, more recently, a searchers. Concurrently with historical studies, a start has, thanks not least to some exchanges with Italian retraordinary architectural heritage of medieval a start has been made to analyze in greater depth Armenia's exand refurbishment of these monuments, Styles, techniques and serves to be analyzed also from this point of view today.
\end{abstract}

Key words historical seismology - Armenia ancient monuments

The disastrous earthquake of 7 December 1988 in Armenia will remain for ever engraved in the memory of the Armenian people as an enormous tragedy: in the space of a few seconds it caused thousands of victims, destroyed towns and villages, reduced to ruins industries, factories, houses, schools and villages, and seriously damaged more than a thousand historic monuments.

The zone affected by the disaster was equivalent to 40 percent of the whole area of the Republic of Armenia, with a population of one million inhabitants. The earthquake caused 25000 victims; 19000 were injured or disabled; and 515000 people left homeless.

The two previous earthquakes in Armenia, no less destructive that the one in 1988, occurred in 1926 and in January 1937. The frequency of earthquakes in Armenia and a long tradition of written culture have led to increasing attention being focused on the historical data with a view to elucidating the periods of recurrence and characteristics of seismic events. The medieval sources themselves are sufficiently detailed to draw regional seismic maps, whose correct utilization should help, from now on, to avoid the serious consequences of future earthquakes. It is only from the Fifties onwards that attempts have been made in Armenia to tackle historic seismology in a serious way, and it is only since the 1988 earthquake that it has come to form an independent scientific discipline. But Armenia, a real open-air museum, has suffered more than one terrible earthquake, with catastrophic damage, in the course of the centuries. The terri- 
tory of historic Armenia, a mountain group known as the Armenian Plateau, occupies an area of $c .300000 \mathrm{~km}^{2}$, and its average altitude is $1500-1800 \mathrm{~m}$. The Armenian Plateau forms part of the Eurasiatic seismic zone. As is well known, Armenia, Asia Minor and Transcaucasia have suffered terrible earthquakes. through the centuries. Their effects, almost always catastrophic, have forced the Armenian people, throughout their history, to continuous works of reconstruction.

The ancient written evidence, like the results of modern scientific research, permit us more precisely to locate the site of seismogenetic structures in those areas where seismic activity has been constantly felt. The earthquakes which have occurred on the Armenian Plateau are often mentioned by medieval historians and chroniclers from the 5th century A.D. to the late medieval period (which for us extends down to the 18th century). European historians and travellers and foreign scientists have also left important sources for a knowledge of Armenian seismicity. In the 19th century some Armenian experts tried to collect the written sources on earthquakes, thus sowing the seeds of historical seismology in Armenia.

In Russia the systematic study of earthquakes began after the earthquakes that occurred in the southern seismic zone of the huge territory of the Russian Empire in 1840. Mouchkétov, Abich, Orlov and Djanachvili were among the first researchers to lay the foundations of the scientific study of the history of earthquakes on the Armenian Plateau. Their numerous chronological, geographic, regional and historical catalogues, the one completing the other, substantially enlarged our knowledge of earthquakes in Armenia.

The works of foreign researchers are for the most part incomplete. Ignorant of the Armenian, Georgian and Persian medieval sources, and more especially the unpublished manuscript literature, these authors were precluded from presenting a comprehensive version of the historical facts relating to the medieval earthquakes and hence establishing their precise succession.

The historian Karapet Kostaneanc' was the first to make a serious effort in 1902 to compile a chronicle of Armenian earthquakes, on the basis of the written sources, by publishing the first catalogue of the earthquakes of Armenia and Asia. His book, entitled «Chronicle of Earthquakes in Armenia», contains a wealth of data on earthquakes in Armenia from antiquity to the 19th century.

In 1930, Busse published a brief chronicle of the major earthquakes in Transcaucasia from 854 to 1929 , describing 17 in all.

Returning later to the description of the earthquakes of Transcaucasia, Busse did not always succeed in gathering all the rich documentation that exists. From this point of view, Stépanjan's work «The Earthquakes of the Armenian Plateau and its Environs» is a very well documented study which also summarises the research conducted in this area in previous years. Stépanjan's researches are based on the data of numerous manuscript and published sources, and represent an important contribution to historical seismology. Piecing together the historico-statistical documentation, Stépanjan shows that the Armenian Plateau and its environs have been the theatre of devastating earthquakes for many centuries and that the main seismic regions continue to be characterized by powerful seismic activity. Stépanjan's last publication (1964) enabled the intensity of the various seismic regions of the Armenian Plateau to be gauged and a map of the main seismic zones in Armenia compiled. The correct utilization of this map should enable localities and buildings to be protected from the serious consequences of future quakes. Stépanjan also compiled a list of the earthquakes that have struck the Armenian Plateau and its environs; it contains reports of no less than 817 earthquakes from the 5 th century A.D. to the earthquake of 18 March 1953 in Anatolia.

The terrible Armenian earthquake of December 1988 has prompted renewed investigation of the historical sources in order to gain a better understanding of the periods of recurrence of major earthquakes. To complete the catalogue compiled by Stépanjan in 1964, Karapétian has, in his work devoted to the geodynamics of the Armenian Plateau, compiled a catalogue of the earthquakes that have oc- 
curred in the Ararat region from antiquity to 1985. The general catalogue that accompanies Karapétian's work (1991) lists 1158 earthquakes from the 6th century down to the earthquake of Khoy of 29 December 1980, comprising both historical and scientific data.

Numerous references to the earthquakes on the Armenian Plateau are to be found in the publications of researchers in Armenia's neighbouring countries: Iran, Turkey, Azerbaijan and Georgia; they have helped to fill gaps and contain valuable information. The earthquakes of the Armenian Plateau are also recorded in the catalogues and specialist literature published by scholars in the former Soviet Union.

The work of Zeyt'unyan (1991), codicologist and historian of Erevan, currently awaiting publication, will make a new contribution to the study and collection of the testimonies of the medieval authors and the data that derive from them. The medieval sources that attest to seismic effects enable us to specify and define the main seismic epicentral zones on the Armenian Plateau and its environs, and to furnish a classification of the territory in terms of seismic hazard.

On the basis of these testimonies, it has already been possible to locate the most dangerous earthquake-source area of historic Armenia in the Yerzynka region (now in Turkish territory). The second most dangerous area, in terms of seismic activity, is that of the Ararat valley, where the frequency of shocks is in fact not less than that of Yerzynka. The third zone includes the plain of Shirak, and the regions of Kars, Erzeroum and Bassen; in their vicinity is the fourth seismic area, consisting of the basin of lake Van, and the territory of Mouch, Ardjech and Khlat. There is also the area of Siounik-Vayots-dzor, a region where major quakes are mentioned from the 8th century on. The statistical analysis of the historical data leads to the conclusion that the Armenian Plateau and its environs constitute an area of marked and frequent seismic activity, which is still in course.

It is clearly impossible to ignore the historical sources; indeed it is indispensable to pay particular attention to them. It is now clear that the data elaborated from the historical sources have provided the basis for the maps of seismic classification of the Armenian Plateau. The further elucidation and investigation of the historical sources may thus enable us to mitigate the consequences of future earthquakes by applying the methods of antiseismic architecture in the zones most exposed to risk.

\section{Earthquakes and historical architecture}

At the present time, alongside the evidence of the medieval sources, a certain importance is also attached to archaeological excavations and to the study of monuments from an historical and architectural point of view. The analysis of the ancient buildings revealed by excavations, and of the medieval monuments still preserved above ground, shows that these buildings have been subjected to violent shocks in the course of their existence. Moreover, the results of the research conducted on them demonstrate that the building techniques developed over the centuries gave them an antiseismic character; based on the experience of local seismicity, these techniques were faithfully applied by the Armenian architects of the time.

At the present time we can speak of «errors» made by ancient architects, but we cannot ignore the evidence: the techniques applied by the ancient master-builders of Armenia ensured more stable and more solid constructions that those observable in the 19th and 20 th century, down to our own day. The study of the architecture and art of the buildings of ancient and above all medieval Armenia, and of its neighbouring countries, shows that, to protect them from earthquakes, importance was in the first place attached to the correct preparation of the foundations, which had to be both homogeneous and elastic. The architecture of Armenian buildings was developed in close relationship with that of neighbouring countries, without avoiding reciprocal influences, and yet at the same time maintaining its own originality and its own national character. Armenian architects ensured the essential prerequisites of antiseismic architecture in time, beginning by drawing up the building's symmetrical plan, 
based on the concentric composition of the whole ensemble.

Thus, if the architect wished to design a domed building, he would begin by drawing up a symmetrical plan, whether circular or square, above which a dome of concentric construction would be raised. The subsequent architecture was developed on this basis. Throughout the first millennium, down to the 7th century A.D., Armenian architects mainly drew on the most important elements of Greek architecture; these were probably able to contribute already to improving the buildings' antiseismic characteristics. I refer, in particular, to the drystone foundations, in which the large blocks of tufa and basalt are laid without mortar and bonded together by iron or bronze clamps soldered with fused lead. This process was replaced, in the 7 th century, by a rubble infill technique, which consisted in filling the cavity between two parallel facing walls of smoothly ashlared tufa or basalt with a mixture of broken stones and clay mortar. At the base the distance between these two facing walls is of no significance, because the building's whole weight is borne by the ashlared blocks. In the upper parts of the walls, by contrast, the latter serve only as revetment and the whole weight of the roof structure is transmitted by the clay mortar, which fills the cavity between the two revetments; this is a technique which ensures the construction of a homogeneous or monolithic wall.

The study of the monuments of Armenian architecture shows that the system of monolithic walls faced on both sides with smoothly ashlared blocks has proved its antiseismic effectiveness in the course of the centuries, repeatedly resisting violent seismic shocks. But we asked ourselves: why is it that this medieval building technique, of so-called «midis» type, which was also applied in the 19th and 20th century and down to our own day, has shown that it no longer responds effectively to earthquakes? Has something changed? In fact it is not enough to repeat a style of construction: it is also necessary to respect other rules.

Recent research has shown that the general character of seismic damage caused to buildings is such that the cracks are mainly vertical.
Cracks occur both above and below doors and windows. On the outer walls they almost invariably descend from the upper edge to the base - even in buildings of two storeys. The first inference that needs to be drawn is that this kind of crack testifies to the weakness of the foundations. Houses built of blocks of smooth tufa and with good-quality mortar tend to resist seismic pressures, whereas most of the buildings of «midis» types, constructed with two facings, often of clay, collapse inwards and are fractured by cracks in various directions.

Heavy and massive buildings are more subject to damage than light ones. The joints between the longitudinal and transverse walls suffer especially in those points where the transverse walls are placed furthest apart. This example of poor imitation of the experiences of the past shows that modern builders do not take the trouble to ensure the quality of the load-bearing parts. In the absence of concrete, the blocks of stone are badly bonded together, while the mortar is friable because it does not contain small pieces of broken stone.

\section{Collaborations in progress}

At the time of the earthquake in 1988, these shortcomings were all too clearly felt. It is enough to say that the cult buildings, churches or chapels most damaged by the quake were those built in the 19th and early 20th century; they were either totally or partially destroyed, whereas the nearby monastic complexes and churches of the Middle Ages were left standing. In the majority of these old monuments only the revetment slabs were dislodged by the quake, while the old walls with clay mortar, endowed with excellent qualities of cushioning and plasticity, being monolithic, continued to bear the weight of the building without collapsing.

These are the preliminary findings. They now offer the chance of stimulating the development of a new scientific field in the Republic of Armenia: historical seismicity, combined with the observation of historic buildings. The development of this field of research, which is 
still in its early days, was stimulated by the earthquake of 1988, which provided the opportunity to increase this sector of observations. After the 1988 quake Armenia became the object of a good deal of international solidarity. I must recall, in this connection, the active and friendly support given to Armenia by the Italian government and Italian experts. Two groups of Italian experts representing the University of Rome, and the faculties of architecture in Milan, Genoa and Venice, arrived in Armenia immediately after the earthquake. The concern and interest shown by Italian architects and scientists in our country and in Armenian historic architecture are confirmed by lengthy experience. A group of well-known experts led by Adriano Alpago-Novello and Paolo Cuneo, recognised authorities on the history of Armenian architecture, arrived in Armenia. In the framework of this collaboration, we also had contacts with the group of Italy's Committee for the Protection of Monuments in Areas of Seismic Risk. In addition, the Faculty of Architecture in Genoa, and the Department of Urbanism at the University of Venice have at various times expressed their wish to participate in the work of reconstruction. Italian architects offered their services in the restoration of the monastic complex of Marmachen in collaboration with Armenian specialists. This is one of the finest monuments of Armenian architecture of the Bagratide era. It celebrated its millennium in 1988. Although the various buildings that compose the complex are still standing, the violent shocks of 1988 caused serious damage, and left dangerous cracks in the masonry which may in future give rise to further collapses. When the plan for future work in cooperation with the Italian experts was formulated, the General Directorate for the Conservation and Utilization of the Historic Monuments of Armenia proposed to the Italian group that it should also contribute to the restoration of one of the most famous Armenian monuments of the early medieval period, damaged by the earthquake: the basilica of Ererouyk, built in the late 4th century A.D. On accepting this proposal, the experts of the Politecnico in Milan visited Ererouyk in late 1989 and began to draw up plans for its restoration.

Another more recent manifestation of this spirit of scientific collaboration is the work in progress between our International Centre for the Seismic Protection of Historic and Cultural Monuments and the SGA Storia Geofisica Ambiente in Bologna: the joint research programmes were established in Armenia; they especially concern the future development of historical seismology, with the application of the most advanced methodology. The collaboration of Italian and Armenian experts in the field of the study of historical seismology, and of seismic archaeology, as in that of the restoration of monuments, will produce the desired results. The moment is perhaps not too far removed when at the side of every monument restored we will raise as a sign of acknowledgement monuments of friendship, inscribed with the names of the States which have given their help and of their best qualified representatives.

\section{REFERENCES}

ABICH, H. (1878-1887): Geologische Forschungen in den Kaukasischen Ländern, Wien, Band 3.

Alı̌san, L. (1870): Memoirs of Armenia, Venezia.

AlIŠAN, L. (1885): Topography of Greater Armenia, Venezia.

AlıšAn, L. (1890): The Region of Ayrarat and Armenia, Venezia (in Armenian).

Ambraseys, N.N. (1974): Historical Seismicity of NorthCentral Iran.

Ambraseys, N.N. and C.P. Melville (1982): A History of Persian Earthquakes (Cambridge University Press).

Aslan, E., L. TERucan and M. BATH (1975): An Earthquake Catalogue for Turkey for the Interval 19131970, Kandilli Observatory Seismological Department Gengelköy-Istanbul, Turkey, and Seismological Institute, Uppsala, Sweden.

Atlas of Earthquakes in the U.S.S.R. (1962): Moscow (in Russian).

Busse, E.I. (1930): Essay on Seismicity in the RSFSR, Tbilisi (in Russian).

Busse, E.I. (1948): Seismic Conditions of Transcaucasia. I. Chronology of Earthquakes in Transcaucasia, Tbilisi (in Russian).

Busse, E.I. (1948, 1952, 1955): Seismic Conditions of Transcaucasia, parts I, II, III, Tbilisi (in Russian).

Chahkatouniantz, H. (1842): Inscriptions of the Cathedral of Etchmiadzine and of the Five Provinces of Ararat, vol. II, Etchmiadzine (in Armenian).

DJANACHVILI, M. (1902): The earthquakes of the past, in 
News of the Caucasian Department of the Russian Geographic Society, vol. 15, Tbilisi (in Russian).

Ergin, K., U. GüçLÜ and Z. Uz (1967-1971): A Catalog of Earthquakes for Turkey and Surrounding Area, Istanbul.

Gorchov, G.P. (1949): Earthquakes on the Territory of the Soviet Union, Moscow (in Russian).

InDJIKIAN, G. (1822): Inscriptions of Ancient Armenia, Venezia (in Armenian).

INDJIKIAN, G. (1855): Ancient Geography of Armenia, vol. I, Venezia (in Armenian).

KARAPÉTIAN, N.K. (1990): The Seismodynamics and Mechanism of the Occurrence of Earthquakes on the Armenian Plateau, Erevan (in Russian).

KARAPÉTIAN, N.K. (1991): Earthquakes of the Armenian Highlands (Seismic Setting), University of Southern California, Los Angeles.

Kondorskaya, N.V. and N.V. Shebalin (1977): New Catalogue of Violent Earthquakes on the territory of the U.S.S.R. from Ancient Times to 1975, Moscow (in Russian).

KostaneanC;, K. (1902): Chronicle of Earthquakes in Armenia, Tbilisi (in Armenian).

Malinovski, K. (1935): Catalogue of Earthquakes of the SSR of Azerbaijan, Works of the Azeri Department of the Transcausasian Branch of the Academy of Sciences of the U.S.S.R., vol. 10, Bakou (in Russian).

MouchKÉTOV, I.V. and A.P. ORLOV (1893): Catalogue of Earthquakes of the Russian Empire, in Memoirs of the Russian Geographic Society, vol. 26, St. Petersburg (in Russian).
ÖCAL, N. (1963): Türkiyenin sismitesi ve zaizale Gögrfyasi 1850-1960, Istanbul.

ÖCAL, N. (1964): Catalogue for Earthquakes in Turkey (1960-1964), Istanbul.

SHEBALIN, N.V. (1974): Epicentres of Violent Earthquakes on the Territory of the U.S.S.R., Moscow (in Russian).

Soultanov, Z.Z. (1964): Earthquakes of Azerbaijan, Bakou (in Russian).

StÉPANJAN, V.A. (1941): The historical documents of Maténadaran relating to the earthquakes on the Armenian Plateau and in its environs, in Scientific Collection of Maténadaran, vol. I, Erevan (in Armenian).

STÉPANJAN, V.A. (1942): Historical account of earthquakes in Armenia and in the surrounding areas, in Transcaucasian Conference on Paraseismic Constructions, Erevan (in Armenian?).

StÉPANJAN, V.A. (1942): Brief Chronology of the Most Violent Earthquakes in Armenia and its Surrounding Regions, Erevan (in Russian).

StÉPANJAN, V.A. (1964): The Earthquakes on the Armenian Plateau and in its Environs, Erevan (in Armenian).

TCHAlENKo, J.S. and Berberian M. (1974): The Salmas (Iran) earthquake of May 6th, 1930, Annali di Geofisica, 27 (1-2), 165-185.

Tzakhakaya, A.D. and B.G. PaPachvili (1973): Seismic Conditions of Caucasia, Tbilisi (in Russian).

ZEYT'UNYAN, A.S. (1991): The Earthquake in Armenia and in Neighbouring Territories (in Armenian), typescript, Academy of Sciences, Erevan. 